\title{
INSTITUTIONAL REGULATION OF THE HEALTHCARE SYSTEM IN THE CONTEXT OF SPREADING COVID-19 IN THE RUSSIAN FEDERATION
}

\author{
Violetta Rusova and Anait Mkrtumova
}

\begin{abstract}
The modern era of globalization creates specific socio-ecological conditions for the existence of the world human community, which, in turn, determine the singularity of the epidemiological behaviour of many infectious diseases. The year 2020 has challenged the humanity with a pandemic that is rapidly spreading around the world. Global relations are fraught with global epidemiological problems. Such manifestations of globalization as intensified international migration of population, roaring international trade in agricultural products, domestic and wild animals and birds, food, raw materials and goods, development of high-speed transport, turn the world into a single global socio-ecological epidemiological system, in which all processes are interconnected and mutually dependent. The purpose of the paper is to study and analyse the system of institutional regulation of the health system in the context of a pandemic. The study used such methods as the analysis method, analogies, comparisons, observations, as well as statistical methods to analyse various indicators necessary for research. Using the above methods, a large amount of literature, legislation, regulatory and institutional regulations on this issue was analyzed, some existing indicators were summarized, and a conclusion was made about the process of institutional regulation in an unfavourable epidemiological situation. As a result of the study, based on a large number of official documents, it was concluded that measures were taken in the Russian Federation to counteract the active spread of a new coronavirus infection. Implementation of the state policy for preventing the spread of the pandemic resulted in no high mortality rate from new coronavirus infection compared to other world states. It should be noted that due to the Federal structure of the country, the heads of regions independently decide on the regulation of mechanisms to counter the spread of infection on the territory of the subject, in this regard, it is not possible to promptly update information on the effectiveness of the measures taken. Currently, the risk-based approach described in the article is a mechanism for studying the epidemiological situation, which allows determining the risk factors that affect it and, on this basis, to rank epidemiological problems by their degree of importance. Due to the fact that the pandemic as a new virus was an unexpected risk, the clinical picture remains blurred, but the institutional form of state regulation is fused to protect the rights of citizens to health care under conditions of the pandemic.
\end{abstract}

Keywords: health care, coronavirus (COVID-19), response strategy, risk-based approach, medical care, government regulation

JEL Classification: I150, I180, I190 


\section{Authors:}

\section{Violetta Rusova}

Saint-Petersburg State University of Economics, 21 Sadovaya street, Saint Petersburg, Russia E-mail: vio.rus.info@mail.ru

https://orcid.org/0000-0002-1816-4295

\section{Anait Mkrtumova}

Saint-Petersburg State University of Economics, 21 Sadovaya Street, Saint Petersburg, Russia E-mail: mkrtumova-anait@mail.ru

https://orcid.org/0000-0002-0640-9945

Citation: Rusova, V., \& Mkrtumova, A. (2020). Institutional Regulation of the Healthcare System in the Context of Spreading COVID-19 in the Russian Federation. Virtual Economics, 3(4), 72-90. https://doi.org/10.34021/ve.2020.03.04(4) 


\section{Introduction}

At the end of 2019, an outbreak of a new coronavirus infection occurred in the people's Republic of China (PRC) with an epicenter in the city of Wuhan (Hubei province), the causative agent of which was given the temporary name 2019-nCoV. On February 11, 2020, the World Health Organization (WHO) assigned the official name of the infection caused by the new coronavirus - COVID-19 ("Coronavirus disease 2019"). On February 11, 2020, the international Committee on virus taxonomy assigned an official name to the infectious agent-SARS-CoV- 2 . The emergence of COVID-19 has given healthcare professionals the task of quickly diagnosing and providing medical care to patients. Currently, information about the epidemiology, clinical features, prevention and treatment of this disease is limited. It is known that the most common clinical manifestation of a new variant of the coronavirus infection is bilateral pneumonia (Ministry of Health of the Russian Federation, 2020).

The spread of the COVID-19 virus between 2019 and 2020 on a global scale has caused an overload of health systems, including social and economic destabilization, suspending public and economic life. This current situation goes beyond the crisis in the field of health, striking and highlighting the problems of all spheres of human life. In a relatively short time, the COVID-19 outbreak is characterized by the following distinctive features. First, the speed and scale of the spread mean a rapid increase in the number of people who have a new viral infection. Secondly, these are the degree of the disease severity and the fatal outcome of sick patients. Third, it is economic and social destabilization, which is a public shock, as a result of restrictive measures taken by various states of the world in order to reduce and control the spread of the virus.

According to the World Health Organization worldwide, as of May 11, 2020, there were $4,013,728$ confirmed cases of COVID-19, including 278,993 deaths reported (World Health Organization, 2020). Thanks to digital technologies, it is now possible to monitor the number of COVID-19 cases online. There is an official website in the Russian Federation https://covid19.rosminzdrav.ru/, whose data is updated automatically, with the reference to the sources: WHO and Rospotrebnadzor. According to official data as of May 11, 2020, the Russian Federation ranks third in the ranking of countries with the number of cases in the world, and the number of deaths is 2009 people. The pandemic outbreak necessitated an analysis of the health care system, since various states were unable to provide human guarantees for health care in the conditions of the virus spread. The restrictions that were used to regulate the spread of this viral infection have changed the philosophy of thinking about health and life in general. Since the restrictive measures were very severe and had a significant impact on the world economy, and the debate about their application does not stop, we have made an analysis of the health care system organization in the country during the period of the COVID-19 spread. 


\section{The Literature Review}

First of all, it should be noted that the article deals with a new virus, which has not been thoroughly investigated yet due to various circumstances. The special complexity of diagnostic measures and laboratory studies is conditioned by the nature of the virus and the geographical and other features of its habitat. In this regard, a rapid response strategy has been chosen in many countries to minimize the spread of infection. Institutional regulation of health care has become particularly important in this regard.

The article analyzes the strategy published by the World Health Organization to combat COVID 19 , which served as methodological recommendations for establishing regulation of the health care system in the Russian Federation (World Health Organization, 2020b)

The analysis of the works by the Russian scientist B. L. Cherkassky "Risk in Epidemiology" and "Global Epidemiology" served as the basis for defining the category of the concept "epidemiological risk". Despite the fact that the problem of the epidemics spread in the context of globalization has been consecrated by the author in his scientific works, the concept of the domestic epidemiology has not been elaborated. Currently, the risk-based approach is a mechanism for implementing control and supervisory activities in the Russian Federation (ALFA.RU, 2020; Cherkassky, 2007).

Temporary recommendations from the Ministry of Healthcare (Ministry of Health of the Russian Federation, 2020) are largely based on the materials devoted to the diagnosis, prevention and treatment of COVID-19 published by WHO, Chinese, American and European centers for disease control, the analysis of domestic and foreign scientific publications, regulatory documents of the Ministry of Healthcare of Russia and Rospotrebnadzor, and serve as a statement intended for heads of medical institutions and their departments, general practitioners, infectious disease specialists, pediatricians, obstetricians and gynecologists, resuscitators of intensive care units in infectious hospitals, emergency physicians, as well as other specialists working in the field of medical care organization for the patients with COVID19.

The analysis of the legal framework for state regulation of the health care system in the context of the COVID-19 spread served as the basis for making a conclusion that the Russian Federation has implemented a mechanism of institutional relations to ensure the citizens' protection.

\section{Methods}

1. The methodological basis of the research is a dialectical method of the reality cognition in its connection and interaction, in the form of an objective, comprehensive and concrete consideration of state and legal phenomena. 
2. In the process of research, the observation method was used, which consists in the object's active, systematic, purposeful, planned and deliberate perception, during which knowledge about the external sides, properties and relations of the object under study is obtained.

3. Applying the scientific method of a description, it was possible to characterize the data presented in the article, using the system of data collection, primary analysis and presentation.

4. The system-structural scientific method of cognition, which is a sequence of actions to establish structural links among variables or elements of the system under study, allowed establishing institutional links of health care system regulation in the conditions of COVID-19 distribution.

5. Using the logical method of scientific knowledge allowed determining the interrelation of goals and objectives to solve the problems that arose to contain the spread of the pandemic in the country.

6. The document analysis method used as a data collection tool in the course of the health regulatory system study identified the existence of institutional impacts on the health care system.

7. The statistical method of scientific knowledge allowed monitoring of fatal outcomes during the spread of a new coronavirus infection.

\section{Results and Discussion}

COVID-19 is a new disease that differs from other diseases caused by coronaviruses, such as severe acute respiratory syndrome (SARS) and middle east respiratory syndrome (MERS) (Ministry of Health of the Russian Federation, 2020). This virus has a distinctive characteristic, which is a rapid spread in the form of an epidemiological outbreak, with an exponential increase in infection. Currently, there are no therapeutics or vaccines with proven treatment or prevention capabilities for COVID-19, although national governments, WHO and its partners are urgently coordinating the accelerated development of medical responses (World Health Organization, 2020).

Coronaviruses (Coronaviridae) are a large family of RNA containing viruses that can infect humans and certain animals. In humans, coronaviruses can cause a range of diseases, from mild forms of acute respiratory infection to severe acute respiratory syndrome (SARS). Four coronaviruses (HCoV-229E, -OC43, -NL63, and-HKU1) are currently known to circulate in the population, which are present year-round in the structure of ARVI, and usually cause mild to moderate upper respiratory tract damage. Based on serological and phylogenetic analysis, coronaviruses are divided into four genera: Alphacoronavirus, Betacoronavirus, Gammacoronavirus, and Deltacoronavirus. The natural hosts of most of the currently known coronaviruses are mammals. Clinical manifestations of acute respiratory infection include body temperature above $37.5{ }^{\circ} \mathrm{C}$ and one or more of the following signs: cough, dry or with 
scant sputum, shortness of breath, chest congestion, blood oxygen saturation according to pulse oximetry $(\mathrm{SpO} 2) \leq 95 \%$, sore throat, runny nose and other catarrhal symptoms, weakness, headache, anosmia, diarrhea - in the absence of other known causes that explain the clinical picture regardless of the epidemiological history (Ministry of Health of the Russian Federation, 2020).

\subsection{The Global Response Strategy for COVID-19}

The World Health Organization has developed a Global response strategy for COVID-19, which aims to control the pandemic by slowing virus transmission and reducing mortality. The global strategic objectives were formed as follows:

- mobilising all structures and populations to fight the pandemic, including hand hygiene, "respiratory etiquette" and physical distancing of everyone;

- controlling sporadic cases and foci, preventing transmission of the virus among the population by quickly identifying and isolating all cases;

- tracking and quarantine;

- reducing mortality by providing appropriate clinical care for COVID-19 patients;

- ensuring continuity of primary health and social care services and protection of firstline workers in the fight against the virus and vulnerable populations;

- developing safe and effective vaccines and therapeutics that can be available and to the required extent, depending on needs.

Achieving the implementation of the global COVID-19 response strategy will depend on the ability of national and regional authorities to meet the key criteria.

First, COVID-19 transmission is controlled at the level of sporadic cases and foci, all of which originate from known contacts with the sick or imported cases, and the number of new cases must be maintained at a level that the health system can handle, while reserving significant resources for medical care.

Second, there are sufficient public health resources to enable a broad transition from detecting and treating serious cases to identifying and isolating all cases, regardless of their severity and origin:

- detection: suspected cases should be recognized soon after symptoms occur through active case detection, self-reporting, entry screening, and other approaches;

- testing: for all suspected cases, test results should be provided within 24 hours of identification and sampling, and sufficient resources should be available to confirm that the virus is not present in patients who have recovered;

- isolation: all confirmed cases have been effectively isolated (in hospitals and/or designated housing in cases of mild or moderate illness, or at home with sufficient support if there is no designated housing) immediately and until they are no longer contagious;

- quarantine: all people who had close contact with the sick were tracked down, quarantined and monitored for a period of 14 days, whether in designated areas or at home. 
Monitoring and support can be provided through visits from local volunteers, combined with phone calls or text messages.

Third, the risks of outbreaks in high-vulnerability areas are minimized, which requires identifying all the main factors and/or causes of increased COVID-19 transmission, with appropriate measures taken to minimize the risk of new outbreaks and hospital-based infection (for example, appropriate prevention and control of infection, including medical triage, and the provision of personal protective equipment in medical and long-term care settings).

Fourth, preventive measures have been introduced at the workplace to reduce risk, including appropriate guidance and resources to promote and implement standard COVID-19 prevention measures, i.e. physical distance, hand washing, "respiratory etiquette" and, possibly, temperature monitoring.

Fifth, the risk of imported cases is managed by analyzing the likely origin of cases and routes of entry, and measures have been implemented to quickly identify and manage cases of suspected disease among passengers (including the possibility of quarantining people arriving from the areas where there is the virus spread among the population).

Sixth, there is full interaction with local authorities, who understand that there is a broad transition to be made from detecting and treating only serious cases to identifying and isolating all cases, that preventive measures regarding behavior must be maintained, and that all citizens play a key role in the feasibility and, in some cases, in the implementation of new controls (World Health Organization, 2020b).

\subsection{A Risk-Based Approach to Epidemiological Hazards}

In 2007, B. L. Cherkasskiy's monograph "Risk in Epidemiology" was published in which, as he himself wrote, an attempt was made to form the concept and methodology of risk assessment in the epidemiology of infectious diseases. In his understanding, an "epidemiological risk" is a complex and multidimensional concept that is inextricably associated with the patterns of occurrence, development and termination of the epidemic process. This concept application in practice is the introduction of a mechanism for studying the epidemiological situation, which allows determining the risk factors that affect it and on this basis to rank epidemiological problems by their degree of importance (ALFA.RU, 2020; Cherkasskiy, 2007).

In 2008, the last monograph of B. L. Cherkasskiy "Global Epidemiology" was published (Cherkasskiy, 2008). It substantiates the position that the modern era of globalization creates specific socio-ecological conditions for the existence of the world human community, which, in turn, determine the singularity of the epidemiological behaviour of many infectious diseases. The main epidemiological consequence of forming a single interconnected, interdependent and interpenetrating world was the formation of a pandemic character of previously local epidemic processes of many infectious diseases, including particularly 
dangerous ones. In this regard, prevention and control of such diseases increasingly require the joint efforts of the health services in developing and economically developed countries that are interested in protecting the health of their populations.

Currently, the risk-based approach is a method of organizing and implementing state control (supervision), in which, in cases stipulated by law, the choice of intensity (form, duration, frequency) of control measures, measures to prevent violations of mandatory requirements is determined by the attribution of the activities by a legal entity, an individual entrepreneur and (or) production facilities used by them in carrying out such activities belong to a certain risk category or a certain class (category) of danger (KonsultantPlus, 2008).

Despite the fact that in the Decree of the President of the Russian Federation of June 6, 2019 No 254 "On the Strategy for the Development of Healthcare in the Russian Federation for the Period up to 2025" among the threats to national security in the field of public health protection there were identified:

- the risk of complicating the epidemiological situation against the background of the unfavorable situation in foreign countries for a number of new and dangerous infectious diseases;

- the risk of new infections caused by unknown pathogens, the introduction of rare or previously unknown infectious and parasitic diseases on the territory of the Russian Federation, the emergence and spread of natural focal infections, spontaneous infection with infectious agents, the return of extinct infections, the overcoming of interspecific barriers by microorganisms;

- the risk of illegal use of biological and other related technologies, the implementation of dangerous man-made activities (including the use of genetic engineering technologies), as well as biological terrorism, the epidemiological health system was not prepared for the threats and challenges that arose (Official Internet Resources of the President of Russia, 2019).

During the COVID-19 coronavirus pandemic, Roszdravnadzor National Institute of Quality developed checklists under the section "Epidemiological safety" for internal control of medical organizations (National Institute for Quality, 2020).

The checklist (list of control questions) is presented in the form of mandatory requirements that are most significant in terms of preventing the threat of harm to the life and health of citizens. Internal control of the quality and safety of medical activities carried out in order to ensure the rights of citizens to receive medical care in necessary quantity and of the appropriate quality in accordance with the orders of medical care, taking into account standards of care and on the basis of clinical recommendations and compliance to ensure the quality and safety of medical activities.

Any healthcare facility in the Russian Federation, regardless of its profile, must have a stepby-step plan of action in case a patient with COVID-19 is identified. The readiness of medical organizations should be checked according to the checklists that were developed by the Federal state budgetary institution "National Institute of Quality" of Roszdravnadzor. 


\subsection{The Key Principles and Methods of Providing Outpatient Medical Care to Patients Diagnosed with COVID-19}

Temporary guidelines by the Ministry of Health of the Russian Federation regulate the algorithm for providing medical care in outpatient settings to patients diagnosed with COVID19.

Upon receiving a positive result of laboratory tests of the patient's biological material for the presence of COVID-19 (hereinafter referred to as the COVID-19 test result), the authorized person of the medical organization:

- notifies the patient of a positive COVID-19 test result;

- notifies the head of the medical organization of a positive COVID-19 test result;

- enters the planned dates for repeated collection of biological material (smears from the nasopharynx and oropharynx) in the log of patients with COVID-19 - 3rd, 11th days;

- organizes the examination of medical organization employees who have come into contact with a sick patient and, if symptoms of acute respiratory viral infection are detected, the collection of their biomaterial (smears from the nasopharynx and oropharynx) for laboratory testing for the presence of COVID-19;

- conducts patients' interviews in order to clarify their status;

- informs the medical professional who is sent to provide medical care to the patient about the positive result of the COVID-19 test.

Medical professionals who provide home health care to patients who test positive for COVID19 must:

- use personal protective equipment (glasses, disposable gloves, respirator of the appropriate protection class, type 1 anti-plague suit or disposable robe, shoe covers);

- have a stock of at least 20 medical masks and offer them to a patient before starting the interview and examination;

- recommend that a patient should wear a medical mask during the examination and interview by a medical professional;

- treat their gloved hands with disinfectant;

- keep personal protective equipment while staying in a patient's apartment;

- after leaving a patient's apartment, remove personal protective equipment, pack it in a class B medical waste bag, and ensure that it is transported for disposal in accordance with the requirements;

- upon completion of medical care to a patient, inform the authorized person of the medical organization about the people who have contact with the patient. Medical care for a patient with a positive COVID-19 test result can be provided at home in the absence of clinical manifestations or a mild course of the disease (body temperature is less than $38.0^{\circ} \mathrm{C}, \mathrm{BDD}$ is less than or equal to 22 per minute, blood oxygen saturation according to pulse oximetry (SpO2) is more than or equal to 93\%, for children -95\% or more).

A patient with a positive COVID-19 test result with a mild course of the disease is recommended to prescribe treatment in accordance with the guidelines of the Ministry of 
Health of the Russian Federation. Patients with lung disease should be informed by a medical worker about the necessity of calling a doctor or ambulance if you feel unwell (body temperature more than $38,0^{\circ} \mathrm{C}$, the appearance of difficult breathing, breath shortness, new or increased cough, lowering the blood oxygen saturation according to pulse oximetry (SpO2) less than 93\%), as well as possible ways of access to medical care. People who live with a patient with a mild disease in the same room should be informed about the risks of COVID-19 disease and the need for temporary residence in another place.

Patients with lung disease and persons living with the patient should be informed that the infringement of sanitary-epidemiological rules, entailed on imprudence mass disease, may bring them to criminal liability under article 236 of the Criminal Code of the Russian Federation. A patient with a mild course of the disease and those living with such a patient should be provided with information materials on the care of patients with COVID-19, and General recommendations for protection against airborne and contact-borne infections. If a decision is made to continue providing medical care to a patient in an outpatient setting (at home), consent to provide medical care in an outpatient setting (at home) and compliance with the isolation regime for treatment of COVID-19 is issued.

A patient with a positive COVID-19 test result should be hospitalized if one of the following circumstances exists:

- one or both SSCs, regardless of the temperature value: BDD 22 or more movements per minute, blood oxygen saturation according to pulse oximetry ( $\mathrm{SpO} 2$ ) less than 93\%;

- a mild course of the disease, if a patient is over 65 years of age or has symptoms of acute respiratory viral infections in combination with chronic heart failure, diabetes, respiratory system disease (bronchial asthma, chronic obstructive pulmonary disease), pregnancy;

- cohabitation with persons belonging to risk groups (persons over the age of 65 , as well as persons suffering from chronic diseases of the bronchopulmonary, cardiovascular and endocrine systems, pregnant women) and the inability to move them out, regardless of the severity of the disease in a patient;

- a mild course of the disease in children under the age of 3 years or the presence of symptoms of acute respiratory viral infections in children under the age of 18 years in combination with chronic diseases: heart failure, diabetes, bronchial asthma, congenital heart and lung diseases that are on immunosuppressive therapy;

- pregnancies.

A medical organization that observes a child with a positive COVID-19 test result and no clinical manifestations of diseases, provides a daily survey by a district nurse (by phone) about the patient's condition at least 2 times a day, as well as the patronage of a district pediatrician at least once every 5 days. A medical organization that observes a child with a positive COVID-19 test result and a mild course of the disease provides a daily survey by a district nurse (by phone) about a patient's condition at least 2 times a day, as well as the patronage of a district pediatrician (paramedic), taking into account a child's condition at least once every 2 days. A legal representative who provides care for a child with a positive COVID-19 test result, who is receiving medical care at home, must be informed about the risks of COVID-19 disease and 
the need to comply with recommendations to get protected from airborne and contact infections, the specifics of caring for patients with this infection, and also have information that breaching sanitary and epidemiological rules that caused a mass illness through negligence may lead to criminal prosecution, article 236 of the Criminal code of the Russian Federation.

\subsection{State Regulation of the Healthcare System in the Context of COVID-19 Distribution}

Thus, in accordance with the Decree of the RF Government dated 27.03.2020 No. 748-R in 2020, the Finance Ministry allocated funds from reserve Fund of the Government of the Russian Federation on granting the budgets of subjects of the Russian Federation to support measures on provision of balanced budgets of the constituent entities of the Russian Federation in the amount of 33.44 billion rubles for the equipment (retrofitting) further created or repurposed bed fund of medical institutions of the Executive authorities of the constituent entities of the Russian Federation in the sphere of health and local municipal governments, to provide medical care to patients with novel coronavirus infection in accordance with the General requirements to the equipment of beds for patients with novel coronavirus infection approved by the Ministry of Health of Russia (The Official Internet-Portal of Legal Information, 2020d).

By the order of the Government dated 17 April 2020, No. 1049-R the reserve Fund allocated 32.4 billion rubles for the following:

- on vehicle (conversion) to be additionally generated, repurposed and (or) modernized hospital beds medical organizations subordinated to Executive bodies of subjects of the Russian Federation in the sphere of health protection and local municipal administrations, in accordance with the minimum requirements for implementation of medical activities aimed at the prevention, diagnosis and treatment of new coronavirus infection;

- to carry out works on provision of centralized supply of medical gases (oxygen); additionally generated, repurposed and (or) modernized hospital beds medical organizations subordinated to Executive bodies of subjects of the Russian Federation in the sphere of health protection and local municipal administrations, in accordance with the minimum requirements for implementation of medical activities aimed at the prevention, diagnosis and treatment of new coronavirus infection;

- to provide medical and other employees of structural divisions of medical organizations subordinate to the Executive authorities of the subjects of the Russian Federation in the field of health protection and local administrations of municipalities with personal protective equipment in accordance with the minimum requirements for the implementation of medical activities aimed at the prevention, diagnosis and treatment of a new coronavirus infection;

- on equipment (re-equipment) of the medical organizations subordinated to Executive bodies of subjects of the Russian Federation in the sphere of health protection and local municipal administrations, in accordance with the orders of medical care for "anesthesiology and reanimatology", "pulmonology" infectious diseases. Funds are allocated separately for agencies such as the FMBA, etc. 
By the order of the Government of Russia No. 974-R of April 12, 2020, the Federal medical and biological Agency was allocated about 640 million rubles from the reserve Fund of the Government of Russia for the conversion of the bed Fund of medical organizations located in closed administrative-territorial entities in order to provide medical care to patients with a new coronavirus infection (The Official Internet-Portal of Legal Information, 2020f).

The government approved a number of measures to simplify the purchase of artificial lung ventilation (ventilator) and extracorporeal membrane oxygenation (ecmo) devices in 2020. So, the Ministry of Industry and Trade will buy devices from a single supplier. In addition, the contracts will provide work and services for the devices' delivery to medical organizations of the Russian Federation. The Ministry of Health will present a list of institutions that need to be equipped with ventilators and ecmo. Recipients will install the devices at their own expense. According to these contracts, the contractor will not provide security for the contract executution or guarantee obligations. However, an advance can be provided for at the rate of $100 \%$ of the contract price within the approved budget commitment limit. Such contracts should be valid until December 31, 2020 at the most (The Official Internet-Portal of Legal Information, 2020b). 10 billion rubles have been allocated for this purpose from the reserve Fund of the Russian Government for the production and purchase of equipment and products for the diagnosis, detection, prevention and treatment of epidemic diseases, personal protective equipment, medicines and medical devices.

Enterprises and companies engaged in the supply of goods, performance of works and provision of services for the state budget will be able to receive up to $50 \%$ of the contract price as an advance. This resolution was signed by Prime Minister Mikhail Mishustin. Previously, the limit on the amount of advances for executors of the state contracts was $30 \%$. The decision to increase it was made as part of the plan of additional measures to ensure sustainable economic development. This measure is designed to support businesses in a difficult situation (The Official Internet-Portal of Legal Information, 2020c).

Measures to regulate prices for medicines approved on 26.03.2020, amendments to Federal law No 61 "on circulation of medicines" from 12.04.2010 will allow the Russian Government to control prices in cases where there is an emergency, the threat of the emergence and spread of infectious diseases, and if within 30 days there is an unjustified increase in prices by more than $30 \%$, with a preliminary decision of the Government to conduct monitoring (RGRU, 2010). This will allow the Government of the Russian Federation, in the event of an emergency and the threat of spreading the diseases that pose a danger to others, to set for 90 days the maximum allowable prices for medicines and medical devices that are not officially included in the list of vital, but in fact become so under certain threats. On March 31, the state Duma and the Federation Council met to approve amendments to the administrative Code of the Russian Federation in connection with the spread of COVID-19. In particular, the changes will affect article 14.4 .2 on liability for violations of legislation on the circulation of medicines (Official Internet Resources of the President of Russia, 2019; RGRU, 2010; The Official InternetPortal of Legal Information, 2020a). 
At the suggestion of the Ministry of Economic Development of Russia, the Council of the Eurasian Economic Commission decided to exempt from customs duties when importing goods necessary to prevent the coronavirus infection from spreading. The duty-free import regime applies to personal protective equipment (masks and respirators, glasses, gloves, suits, Shoe covers), vaccines, laboratory reagents, boxes and stretchers for transporting patients, bags for transporting hazardous biological waste, blood transfusion systems, tubes for artificial ventilation, syringes and catheters, materials used for producing personal protective equipment, disinfectants. The measure applies to goods imported between March 16 and September 30, 2020 (ALFA.RU, 2020).

The Ministry of Health approved a temporary procedure for organizing work to prevent and reduce the risks of COVID-19 spread. Medical organizations will be guided by it until 2021. This document contains temporary rules for organizing:

- provision of emergency, including emergency specialized, medical care (Appendix N 2 to the order);

- work of medical organizations providing medical care on an outpatient basis and in a day hospital (Appendix N 3 to the order).

For hospitals, the basic principles of organizing medical care for those who are ill with COVID-19 are defined (Appendix $\mathrm{N} 5$ to the order). To prevent nosocomial spread of coronavirus infection, a Protocol of measures is provided (Appendix $\mathrm{N} 7$ to the order).

In the order, medical workers will be able to find algorithms for actions when providing medical care:

- in outpatient conditions for patients with ARVI (Appendix N 4 to the order);

- in hospital conditions for patients with ARVI and viral pneumonia (Appendix N 6 to the order).

The order provides for the creation of special centers where you can get information support on the diagnosis and treatment of COVID-19 and pneumonia. For example, we are talking about federal and regional remote consultation centers of anesthesiology and resuscitation for adults, children and pregnant women (GARANT.RU, 2020).

In view of non-fulfillment of the Order of the President of the Russian Federation as of April 15, 2020 No PR-665 "List of instructions on countering the spread of a new coronavirus infection (COVID-2019)" in the regions of the Russian Federation" no additional payments were paid for special working conditions to health care workers whose activities are directly related to providing medical care to patients with a new coronavirus infection (COVID-2019) (Official Internet Resources of the President of Russia, 2020a). The Ministry of Health of the Russian Federation in connection with the numerous requests received by medical organizations for implementing incentive payments for performing particularly important work to medical and other employees directly involved in providing medical care to citizens 17.05.2020 clarified that a one-time surcharge for each month is calculated in the prescribed amount ( 80 thousand, 50 thousand or 25 thousand rubles). It is paid in full if an employee has 
worked according to the approved schedule. However, the number of shifts and (or) hours does not matter: the surcharge is provided for the risk of working with patients with coronavirus.

Surcharges are made within the time limits set by the organization for transferring salaries. Incentive payments should include the following:

- coefficients (regional, for work in desert and waterless areas, in high-altitude areas);

- percentage allowances for work experience in areas with special climatic conditions.

At the hospitals treating COVID-19, the head of the medical organization forms its temporary staff schedule and, if necessary (including when repurposing), redistributes the functionality of physicians. Thus, the positions of all health workers who are directly involved in the care of patients with coronavirus are included in the corresponding list. It includes those who are entitled to incentive payments (ALFA.RU, 2020).

The question of the reason for the relatively low incidence in Russia is closely related to the methods of detecting and registering COVID-19. The relatively low incidence in Russia at the first stages was associated with lower coverage of the population with diagnostic COVID-19 tests in comparison with other countries. However, current data show a high level of coronavirus testing in the Russian Federation per one citizen. Another reason for possible underestimation of the real number of cases at the first stages is the relatively low sensitivity of some diagnostic COVID-19 tests, according to some experts, that is, a high number of false negative results. This leads to a different cause of death being indicated (for example, SARS).

The American newspaper The New York Times, citing demographers, writes that the number of coronavirus infection victims may be slightly higher than the official statistics in Russia report. The newspaper published a letter from the head of the Moscow health Department, Alexey Khripun, in which he responds to suspicions of understating the death rate from coronavirus in the Russian capital (Khripun, 2020).

For health care in different countries, the most important thing when monitoring COVID-2019 is to obtain reliable statistical data on the situation of morbidity and mortality associated with COVID-19. Russian statistics of COVID-19 mortality are based on new principles established by the World Health Organization's International classification of diseases (ICD-10), taking into account International guidelines for certifying and coding COVID-19 as a cause of death. When choosing the cause of death in cases related to COVID-19, it was recommended to use rules similar to those for the flu. All deaths associated with COVID-19 Are divided into two groups: cases where COVID-19 is stated as the initial cause of death; cases where COVID-19 is stated as the other cause of death, including cases where COVID-19 is significant in the development of the underlying disease and its fatal complications. Most often, if the ICD-10 rules are followed when selecting the underlying disease in the COVID-19-related cases, the selected disease will be the original cause of death. However, it should be noted that in all cases, the certificate must indicate the logical sequence of pathogenesis of death from COVID-19. Therefore, the diagnosis must necessarily reflect all the existing complications, which in case 
of a fatal outcome are the direct and intermediate causes of death indicated in the chain of events that led to death. An error in issuing a death certificate is recording the cause of death in a single line without a logical sequence of States (World Health Organization, 2020).

The regulatory framework for medical organizations was insufficient to respond quickly to the situation with coronavirus. This applies to the following:

- regulation of changes in the profile of medical organizations in the context of the coronavirus spread;

- legislation in the field of compulsory medical insurance, which did not provide for mechanisms to compensate for the loss of income of medical organizations, their work in standby mode;

- a permissive sphere of medical care: the need to have licenses for medical activities when temporarily converting medical organizations into infectious, pulmonological, as well as in terms of providing telemedicine services by doctors from home;

- qualification requirements for medical professionals: internship (residency), professional training, certificates (certificates of accreditation), if necessary, doctors of other specialties to provide medical care to patients with coronavirus;

- the labor legislation (inconsistency of legislation in relation to distance labor, loan labor)

- legislation in the field of telemedicine technologies.

\section{Conclusions}

The era of globalization creates specific socio-ecological conditions for the existence of the global human community, which, in turn, determine the singularity of the epidemiological behavors of many infectious diseases. The year 2020 has challenged the humanity with a global pandemic that is rapidly spreading around the world.

The emergence of COVID-19 has given healthcare professionals the task of quickly diagnosing and providing medical care to patients. Currently, information about the epidemiology, clinical features, prevention and treatment of this disease is limited.

The global response strategy developed by the WHO has set goals and targets for countries around the world to control the pandemic by slowing down virus transmission and reducing mortality.

The analysis of the works by the Russian scientist B. L. Cherkasskiy "Risk in Epidemiology" and "Global Epidemiology" served as the basis for defining the category of the concept "epidemiological risk". Despite the fact that the problem of spreading pandemics in the context of globalization has been consecrated by the author in scientific works, the concept of the domestic epidemiology development has not been elaborated. Currently, the risk-based approach is a mechanism for implementing control and supervisory activities in the Russian Federation. 
Temporary guidelines by the Ministry of Health of the Russian Federation regulate the algorithm for providing medical care to patients diagnosed with COVID-19.

The analysis of the legal framework for state regulation of the health system in the context of the spread of COVID-19 served as the basis for establishing the conclusion that the Russian Federation has implemented a mechanism of institutional relations to ensure the protection of citizens.

\section{References}

ALFA.RU (2020). Reshenie Soveta EEK ot 08.04.2020 № 38 "O vnesenii izmeneniya v Reshenie Soveta Evrazijskoj ekonomicheskoj komissii ot 16 marta $2020 \mathrm{~g}$. N 21" [Decision of the EEC Council dated 08.04.2020 No. 38 "On Amending the Decision of the Council of the Eurasian Economic Commission dated March 16, 2020 No. 21"]. https://www.alta.ru/tamdoc/20sr0038/ [in Russian].

Cherkasskiy, B.L. (2007). Risk v epidemiologii [Risk in Epidemiology]. Moscow: Prakticheskaya meditsina - Practical medicine. [in Russian].

Cherkasskiy B.L. (2008). Global'naya epidemiologiya [Global Epidemiology]. Moscow: Prakticheskaya meditsina - Practical medicine. [in Russian].

Khripun, A. (2020, May 18). Covid-19 Deaths in Moscow: The Government's Account. The New York Times. Retrieved from https://www.nytimes.com/2020/05/18/opinion/letters/coronavirusrussia-moscow.html

KonsultantPlus. (2020). Pis'mo Minzdrava Rossii ot 17.05.2020 N 16-3/l/1-3061 „Ob osushchestvlenii vyplat stimuliruyushchego haraktera za vypolnenie osobo vazhnyh rabot medicinskim i inym rabotnikam, neposredstvenno uchastvuyushchim v okazanii medicinskoj pomoshchi grazhdanam, u kotoryh vyyavlena novaya koronavirusnaya infekciya COVID-19" [Letter of the Russian Ministry of Health N 16-3/I/1-3061 of 17 May 2020 "About the implementation of incentive payments for performing particularly important work to medical and other employees directly involved in providing medical care to citizens who have been diagnosed with a new COVID-19 coronavirus infection] Retrieved from http://www.consultant.ru/document/cons_doc_LAW_352690/\#dst0 [in Russian].

KonsultantPlus. (2008). Federal'nyj zakon "O zashchite prav yuridicheskih lic i individual'nyh predprinimatelej pri osushchestvlenii gosudarstvennogo kontrolya (nadzora) i municipal'nogo kontrolya" ot 26.12.2008 N 294-FZ [The Federal Act No. 294-FZ of 26 April 2008 "About the Protection of the Rights of Legal Entities and Individual Entrepreneurs in the Exercise of State 
Control (Supervision) and Municipal Control']. Retrieved from http://www.consultant.ru/document/cons_doc_LAW_83079/[in Russian].

Ministry of Health of the Russian Federation. (2020, April 28). Profilaktika, diagnostika i lechenie novoj koronavirusnoj infekcii (COVID-19) Versiya 6 utverzhdena Minzdravom RF. [Prevention, diagnosis and treatment of new coronavirus infection (COVID-19). Version 6" approved by the Ministry of Health of the Russian Federation]. Moscow: Ministry of Health of the Russian Federation. Retrieved from https://minzdrav.midural.ru/uploads/COVID_method_view.pdf [in Russian].

National Institute for Quality. (2020). Chek-listy dlya organizacii i provedeniya vnutrennego kontrolya po razdelu „Epidemiologicheskaya bezopasnost"” v period pandemii koronavirusa COVID-19. [Checklists for organizing and conducting internal control under the section "Epidemiological safety" during the COVID-19 coronavirus pandemic]. Retrieved from http://nasci.ru/?id=10746 [in Russian].

Official Internet Resources of the President of Russia. (2020a). Perechen' poruchenij po voprosam protivodejstviya rasprostraneniyu novoj koronavirusnoj infekcii (COVID-2019) v regionah Rossijskoj Federacii N 665 ot 15.04.2020 [List of instructions on countering the spread of a new coronavirus infection (COVID-2019) No 665 of 15 April 2020]. Retrieved from http://kremlin.ru/acts/assignments/orders/63206 [in Russian].

GARANT.RU. (2020). Prikaz Ministerstva zdravoohraneniya RF ot 19 marta 2020 g. № 198n "O vremennom poryadke organizacii raboty medicinskih organizacij $v$ celyah realizacii mer po profilaktike i snizheniyu riskov rasprostraneniya novoj koronavirusnoj infekcii COVID-19" [Order of the Ministry of Health of the Russian Federation of March 19, 2020 No. 198n "On the temporary procedure for organizing the work of medical organizations in order to implement measures to prevent and reduce the risks of the spread of a new coronavirus infection COVID-19"]. Retrieved from https://www.garant.ru/products/ipo/prime/doc/73669697/ [in Russian].

Official Internet Resources of the President of Russia. (2019). Ukaz Prezidenta Rossijskoj Federacii ot 06.06.2019 g. № 254 „O Strategii razvitiya zdravoohraneniya v Rossijskoj Federacii na period do 2025 goda" [Decree of the President of the Russian Federation of 06.06.2019 No. 254 "On the Strategy for the development of healthcare in the Russian Federation for the period up to 2025"]. Retrieved from http://www.kremlin.ru/acts/bank/44326 [in Russian].

RGRU. (2010). Federalnyi zakon "Ob obrashchenii lekarstvennyh sredstv" ot 12.04.2010 N 61-FZ [The Federal Act No. 61-FZ of 12 April 2010 "About Circulation of Medicines]. Retrieved from https://rg.ru/2010/04/14/lekarstva-dok.html [in Russian].

The Official Internet-Portal of Legal Information. (2020a) Federalnyi zakon ot 01.04.2020 N 99-FZ "O vnesenii izmenenij v Kodeks Rossijskoj Federacii ob administrativnyh pravonarusheniyah" [The Federal Act No. 99-FZ of 1 April 2020 "About the Amendments to the Russian Code of Administrative 
Offences"]. Retrieved from http://publication.pravo.gov.ru/Document/View/0001202004010076 [in Russian].

The Official Internet-Portal of Legal Information. (2020b). Postanovlenie Pravitel'stva Rossijskoj Federacii ot 21.03.2020 N 323 "Ob avansirovanii gosudarstvennyh kontraktov na osushchestvlenie Ministerstvom promyshlennosti i torgovli Rossijskoj Federacii zakupok apparatov iskusstvennoj ventilyacii legkih i ekstrakorporal'noj membrannoj oksigenacii, vklyuchayushchih raboty i uslugi po ih dostavke v medicinskie organizacii v sub"ektah Rossijskoj Federacii" [Decree of the Government of the Russian Federation of March 21, 2020 No. 323 "On advancing government contracts for the procurement of artificial ventilation devices and extracorporeal membrane oxygenation by the Ministry of Industry and Trade of the Russian Federation, including works and services for their delivery to medical organizations in the constituent entities of the Russian Federation"]. Retrived from http://publication.pravo.gov.ru/Document/View/0001202003230004 [in Russian].

The Official Internet-Portal of Legal Information. (2020c). Postanovlenie Pravitel'stva Rossijskoj Federacii ot 30.04.2020 № 630 "O vnesenii izmeneniya v postanovlenie Pravitel'stva Rossijskoj Federacii ot 24 dekabrya 2019 g. № 1803 i o priostanovlenii dejstviya otdel'nyh polozhenij nekotoryh aktov Pravitel'stva Rossijskoj Federacii" [Resolution of the Government of the Russian Federation of April 30, 2020 No. 630 "On Amending the Resolution of the Government of the Russian Federation No. 1803 of December 24, 2019 and on the Suspension of Certain Provisions of Certain Acts of the Government of the Russian Federation"]. Retrieved from http://publication.pravo.gov.ru/Document/View/0001202005030003 [in Russian].

The Official Internet-Portal of Legal Information. (2020d). Rasporyazhenie Pravitel'stva Rossijskoj Federacii ot 27.03.2020 № 748-r [Order of the Government of the Russian Federation dated March 27, 2020 No. 748-r]. Retrieved from http://publication.pravo.gov.ru/Document/View/0001202003300026 [in Russian].

The Official Internet-Portal of Legal Information. (2020f). Postanovlenie Pravitel'stva Rossijskoj Federacii ot 02.07.2020 № 974 "O vnesenii izmenenij v nekotorye akty Pravitel'stva Rossijskoj Federacii" [Resolution of the Government of the Russian Federation dated 02.07.2020 No. 974 "On Amending Certain Acts of the Government of the Russian Federation"]. Retrieved from http://publication.pravo.gov.ru/Document/View/0001202007100028 [in Russian].

World Health Organization. (2020, April 16). Certification and Classification (Coding) of Covid-19 as Cause of Death. Geneva, Switzerland: World Health Organization. Retrieved from https://www.who.int/classifications/icd/Guidelines_Cause_of_Death_COVID-19.pdf?ua=1

World Health Organization. (2020a). Retrieved from https://www.who.int/ 
World Health Organization. (2020b, April 14). COVID-19 Strategy Update. Geneva, Switzerland: World Health Organization. Retrieved from https://www.who.int/docs/defaultsource/coronaviruse/covid-strategy-update-14april2020.pdf?sfvrsn=29da3ba0_19 